\title{
The Theological Accentuation
}

\section{Theological Foundations}

In the manifesto from 1958, Tang and his co-authors suggested that Confucianism is characteristically based on a notion of human nature (xing 性). In explicit accordance with Confucian and neo-Confucian predecessors, Tang placed the human being at the center of a cosmic order which he referred to as "Heaven" (tian 天). Similar to Wang Yangming's "study of the mind," Tang singled out, as we have seen, a passage from Mencius virA.1: "Mencius said, 'For a man to give full realization to his heart (jin qi xin) is for him to understand his own nature (zhi qixing), and a man who knows his own nature will know Heaven (zhi tian)."' Tang interpreted this as a proposition about the human being's potential to fully actualize him- or herself. This actualization is said to be equivalent to a "penetrating awakening" which allows the human mind to access "the ultimate source of the universe and human life" (yuzhou rensheng zhi benyuan 宇宙人生之本原). In this sudden realization, then, the human being will apprehend Heaven and hence the spiritual source of all reality. ${ }^{3}$

What Tang meant by "mind" may be approximated by reference to Max Scheler's broad concept of mind (Geist), which ascribes to it discursive thought (Ideendenken) as well as “[a] specific type of 'intuition' (Anschauung) ... of original phenomena or contents of essence" and thus "a specific class of voli-

1 Zhang, Zhongguo wenhua yu shijie, p. 25.

2 Lau, Mencius, p. 182; see Tang, Renwen jingshen zhi chongjian, p. 6o; see also Zhang, Zhongguo wenhua yu shijie, pp. 23-24. For a concise discussion of Mencian speculation and its impact on neo-Confucianism, see Tang, Zhexue gailun, Vol. 2, pp. $369-380$. Mencius VIIA.1 is of great importance for Wang Yangming's thought: see Wang, Chuan xi lu, p. 20 (see also Chan, Instructions for Practical Living and other Neo-Confucian Writings by Wang Yang-ming: I.6), 101 (ibid., I.66), 202 (ibid., II.134), 216 (ibid., II.136), 334 (ibid., III.174).

3 Tang, Renwen jingshen zhi chongjian, p. 577. Tang provided equivalent formulations such as the ability of the human being to penetrate the "metaphysical ultimate source of universe" (yuzhou zhi xingshang de benyuan 宇宙之形上的本原) or the “absolute pattern of Heaven" (juedui de tian li 絕對的天理): Tang, Renwen jingshen zhi chongjian, p. 586; also cf. Zhang, Zhongguo wenhua yu shijie, p. 29 where the authors state that the human mind can "penetrate the mind of Heaven" (tong yu tian xin 通於天心).

(C) THOMAS FRÖHLICH, 2017 | DOI 10.1163/9789004330139_006 
tional and emotional acts such as benevolence, love, remorse, awe, intellectual amazement, beatitude, and despair, free choice." ${ }^{4}$ Referring to Confucian and neo-Confucian speculation with a similarly broad concept of mind, Tang used the Chinese word $x^{5}{ }^{5}$ and assumed that "mind" appears in the realm of finite being, which includes the human being. He identified xin as the essence, the inner principle of the human being and, as such, as the subjective mind which functions as the intermediary or agent of Heaven: "In this, as seen with regard to the way of Heaven, the fulfilling of this mind and this principle by this human being is indeed the self-realization of the way of Heaven (tian dao zhiziji shixian 天道之自己實現).”

Tang's "study of mind and (human) nature" rests on three basic assumptions: 1) the foundation of all life in a cosmic process referred to as "Heaven"; 2) the possibility of human self-elevation to the point where the human being partakes in the "way of Heaven;" and 3) the essential unity of human existence to be achieved through a human being's insight into the absolute ("Heaven"). ${ }^{7}$ By inscribing these assumptions into a theological framework, Tang distinguished his speculation from the thought of Mencius and Wang Yangming. What is at stake here is the epistemological status of the speculation on human nature. The locus classicus is Mencius IIA.6, which depicts the famous instance of someone experiencing an instantaneous urge to save a child from falling into a well. To be sure, neither Mencius nor Wang ever narrated such an instance in order to discuss the epistemological implications of making propositions about human nature. But the question remains as to whether they understood this narrative as an allegory, as an observation or as something else. ${ }^{8}$ Possibly,

4 Scheler, Schriften zur Anthropologie, p. $15^{8}$ (my translation).

5 Tang distinguished between "mind" and "consciousness," translating the latter in most cases with the neologism $y i s h i$ 意識.

6 Tang, Wenhua yishi yu daode lixing, p. 369. Tang's notion of such a relation between the human and the Heavenly mind is in loose convergence with Scheler's metaphysical anthropology. Tang studied Scheler's thought however only in passing; cf. a brief reference in Tang, Zhexue gailun, Vol. 2, p. $65^{2}$.

7 Roger Ames suggests a fundamentally different understanding of Tang's speculation which he describes as "a radical empiricism" that offers "an understanding of agency [which] is wholly naturalistic in that it makes no appeal to a metaphysics of self" (p. 150). Ames is accordingly compelled to translate Tang's use of term tiandao 天道 with such variants as "the natural and cultural processes," or the "natural and cultural legacy," (p. 145); see Ames, "Achieving Personal Identity in Confucian Role Ethics: Tang Junyi on Human Nature as Conduct."

8 Iso Kern speaks of Mencius' "examples" that Wang Yangming had taken up, albeit with a different interpretation; see Kern, Das Wichtigste im Leben, pp. 208-210. 
they presumed to identify here an empirically accountable proposition about the essential dispositions of human beings. Wang's discussion of such dispositions, especially of those mentioned in Mencius IIA.6, shows that he believed that human beings were naturally endowed with a potential to act upon moral intuition ("innate knowing": liang zhi). The following passage from the Chuan xi lu with its rhetorical question is telling in this regard: "When I see a child fall into a well [and have a feeling of commiseration], there must be the principle of commiseration. Is this principle of commiseration actually in the person of the child or is it in the innate knowledge (liang zhi-TF) of my mind?"9 Unlike Mencius and Wang, Tang explicitly reflected on the epistemological status of his speculation on human nature and moral intuition. He interpreted the Mencian proposition on human nature and the possibility to "know Heaven" as a statement of religious conviction or "faith" (xinyang 信仰):

That all human beings are equal in their nature and that there is nothing which [by nature] is not good in them, is [a matter of] a transcending faith. As it [= this faith] cannot seek to obtain encompassing proof by direct experience, there is nothing I can do, if you want to raise doubts. But this faith itself flowed from the inner spirit of a human being endowed with the spirit of humaneness. If a human being thoroughly recognizes its own humaneness and the goodness of its nature, it will spontaneously be able to suddenly attain the [following] immediate realization: in the nature of all human beings, there is nothing that is not good, and nobody is not endowed with humaneness. ${ }^{10}$

By rephrasing the Mencian idea of human nature as a matter of religious faith, Tang shifted the foundation of his reflections. He accordingly ascribed to his modern Confucianism the quality of "religiosity" (zongjiaoxing), and hence related it to the field of religions.

Tang's notion of religion puts strong emphasis on how religions respond to human concerns about the highest good, eternal justice, a higher truth, the

Wang, Chuan xi lu, p. 209 (Chan, Instructions for Practical Living and other Neo-Confucian Writings by Wang Yang-ming: II.135) as translated in Chan, Instructions for Practical Living and other Neo-Confucian Writings by Wang Yang-ming, p. 99. his "faith" (xin) in liang zhi at the latest stage of his philosophical work. According to Kern's impressive study on Wang, this stage was marked by Wang's new, "religiousenthusiastic" concept of liang zhi; see "Kern, Das Wichtigste im Leben, pp. 187-189. 
eradication of sin and evil, or an afterlife. ${ }^{11}$ He assumed-in the comparative context of the world religions - that religions provide the human beings with answers to their longing for immortality (Daoism), absolute justice (Islam), overcoming pain and suffering (Buddhism), and redeeming sin and evil (Christianity). What is more, religions characteristically "confirm" the existence of an afterworld, including notions of immortality, an afterlife or resurrection, as well as notions of God, Allah, Brahman, Buddha, Bodhisattva or the Immortals. ${ }^{12}$ Tang added that a human being needs myths, miracles, and artistic representations of religious notions in order to "break through" to the sphere of religion. Myths, miracles, and religious art thus fulfill a double function by fostering the belief in a transcendent power, while at the same time expressing the human longing for transcendence. Nevertheless, neither myths nor miracles are the defining features of Tang's concept of religion. ${ }^{13}$ In reflecting on the distinction between (world) religions and (Confucian) religiosity, Tang pointed out that Confucian religiosity did not evolve out of notions of miracles, myths, original sin, and divine grace. ${ }^{14}$ Still, the Confucian person is said to believe in a "transcendent power" (chaoyue liliang 超越力量). ${ }^{15}$ The manifesto of 1958 even suggests that the Confucian belief reaches deep enough into individuals to produce Confucian martyrs. ${ }^{16}$ This reference to Confucian martyrs echoes Zhang Taiyan's claim that the Confucian martyr's spirit is manifest in the Confucian's willingness "to die in the performance of benevolence."17 The idea of a Confucian belief in a "transcendent power" is crucial for Tang's reflection on modernity. He suggested that religions and religiosity might play an important part in deflecting the danger of a Western type of modernity which submits mankind to materialism, positivism, and instrumental rationality. ${ }^{18}$ In the future, Western culture should therefore "revert to the

11 Tang, Zhongguo renwen jingshen zhifazhan, pp. 363-364, 368, 380-385; Tang, Renwen jingshen zhi chongjian, pp. 587-589.

12 Tang, Renwen jingshen zhi chongjian, p. 587.

13 Tang, Zhongguo renwen jingshen zhi fazhan, pp. 363-364.

14 Tang, "The reconstruction of Confucianism and the Modernization of Asia," pp. ${ }^{66-367}$; Tang, Zhongguo renwen jingshen zhi fazhan, pp. 363-365.

15 Ibid., p. 364.

16 Zhang, Zhongguo wenhua yu shijie, pp. 19-20.

17 See chap. 5 (“Ru xia” 儒俠) in Zhang's Book of Persecutions (Qiushu 訄書 [old edition, published in 1900 or 1901]); quoted from: Shimada, Pioneer of the Chinese Revolution, p. 112.

18 Tang listed the following philosophical opponents of religions: materialism (most dangerous in his eyes), logical positivism, empiricism and, to some degree, naturalism; see Tang, Renwen jingshen zhi chongjian, p. 595 . 
divine" in order to avoid the reification of the human being as a material object. What is necessary, in other words, is a "revival" of religions, and hence the common perspective of world religions and Confucian religiosity in modernity. ${ }^{19}$

By emphasizing the religious core of Confucianism, Tang addressed an issue which had been raised by Max Weber, who famously denied that Confucianism had any metaphysical or religious outlook. Weber made this assertion in the context of his large-scale comparative investigation into the formation of modernity. Tellingly, the manifesto A Declaration to the World for Chinese Culture from 1958 thoroughly refutes the Weberian notion that "Chinese culture" is void of "transcendent feeling of a religious nature"20 _ albeit without explicit mention of Weber's thesis about Confucianism.

An important aspect of Tang's version of Confucian religiosity concerns its ritualistic elements. Tang strongly highlighted the so-called "three forms of ritual sacrifice" (san ji 三祭) to "Heaven and Earth" (tian di 天地), to the "ancestors" (zuzong 祖宗), and to "saints and worthies" (sheng xian 聖賢). He was convinced that these rituals had existed over a long period of time and were practiced within a large segment of society. ${ }^{21}$ For reasons which he did not elaborate, he treated these rituals as specifically Confucian, and even identified them as the "center" of Confucian rituals. ${ }^{22}$ The rituals not only entailed the worship of Heaven and Earth, the ancestors, and the saints and worthies, but also the Heavenly call to the worshippers to realize their individual selffulfillment in intuition. If the rituals are carried out with attentiveness, the creative "virtues" (de 德) of Heaven and Earth, of the "lord on high" (shangdi 上帝), of the ancestors, and of the saints and worthies might “appear" (cheng 呈) in the mind of the worshipper and "directly manifest [themselves]" (zhijie biaoxian 直接表現). ${ }^{23}$ In the course of the rituals, the worshipper thus realizes that he or she is summoned to "connect in [mutual] affection" (gantong 感通) with a transcendent existence. ${ }^{24}$ The worshipper can then "set the self at ease

19 Tang, Renwen jingshen zhi chongjian, pp. 26-27.

20 Zhang, Zhongguo wenhua yu shijie, p. 16.

21 Tang, Zhongguo renwen jingshen zhi fazhan, p. 374.

22 Ibid., p. 389. On the three forms of ritual sacrifice, see also: Tang, Zhongguo renwen jingshen zhi fazhan, pp. 374-389; Tang, "The reconstruction of Confucianism and the Modernization of Asia," pp. 363-364.

23 Tang, Zhongguo renwen jingshen zhifazhan, p. 387.

24 Ibid., p. 375. For Tang, "gantong" is a mode of activity in which recognizing, feeling and intending are simultaneously taking place and the distinctions between agent/receptor and subject/object are suspended. The scope of gantong is not limited to religious experience, but may also include sensory perception and intellectual activity. On gantong see Liao, “Tang Junyi 'panjiao lilun' de chubu kaocha," pp. 40-44. As for the relation between 
and establish destiny” (an shen li ming 安身立命), thereby realizing the fundamental sense of the "Confucian teachings" (Ruzhe zhi jiao 儒者之教). ${ }^{25}$

Tang further explained that the notion of the human condition, as manifest in these rituals, is not determined by feelings of sinfulness, as in Christianity, nor by an existence marked by pain and suffering, as in Buddhism. Instead, these rituals express the aspiration of the Confucian worshipper to "transcend" or "enlarge" his or her "self" (zi wo 自我), and thus "permeate" (tong $d a$ 通達) Heaven and Earth, the ancestors, and the saints and worthies. ${ }^{26}$ In pathos-rich language, Tang assumed in this context that the "pure Chinese" (chuncui de Zhongguoren 純粹的中國人) who believe in Confucianism are convinced that they can fulfill the "essence" (benzhi 本質) of the human spirit. But to achieve this it will not suffice to simply "establish destiny" in philosophy, science, literature, art, politics, or economy. One also has to reach for the infinite "realm" (jingjie 境界) beyond these fields. ${ }^{27}$ Against this backdrop, Tang called for a contemporary revival of Confucian ritual practice, including rites de passage which should not be left entirely to the followers of other religions. ${ }^{28}$

The (modern) Confucian faith is, according to Tang, not a matter of revelation, but is based on human reason and feeling and is characterized by a conflation of belief and knowledge in the ultimate realm of insight into the absolute. ${ }^{29}$ Tang's theological metaphysics thus contains a medial doubleprinciple (mediales Doppelprinzip), to borrow a term from research on Fichte: in an act of intuition, the human mind recognizes and realizes itself as an appearance of Heaven, and at the same time, Heaven manifests itself through intuition, thereby recognizing itself in the human mind. ${ }^{30}$ As Tang put it: "Heaven recognizes [itself]" (tian zhi 天知) as it "appears" in the human "self," and the self-realization of Heaven is "identical" with intuition. ${ }^{31}$ In partaking in the self-attainment of Heaven, the human mind is lifted above itself. Still, this self-transcendence does not extinguish the human mind, and the

gantong and liang zhi, one might tentatively propose that the mode of cognition in liang $z h i$ is to be called gantong.

25 Tang, Zhongguo renwen jingshen zhi fazhan, p. 365 .

26 Ibid., p. 384 .

27 Ibid., pp. 365-366, 374-375.

28 Ibid., p. 390.

29 Tang, "The Reconstruction of Confucianism and the Modernization of Asia," p. 363. In this conflation, Tang's theological metaphysics is similar to Fichte's metaphysical realism; on Fichte see Oesterreich, Der ganze Fichte, pp. 203-204.

30 For a discussion of the medial double-principle in research on Fichte's allegories of light see Oesterreich, Der ganze Fichte, pp. 221-224.

31 Tang, Renwen jingshen zhi chongjian, p. 587. 
difference between the mind of Heaven, which Tang understood as a metaphysical reality, and the human mind is preserved in the illuminated mind as "the sage mind." ${ }^{32}$ According to this notion of the absolute, Heaven attains selfrealization by manifesting itself in the mind of the human being (the "sage"; sheng ren 聖人), whereas the latter apprehends in an act of (moral) intuition the ultimate principles of reality (the "principles of Heaven"). ${ }^{33}$

With respect to notions of the sage in Chinese history, Tang explained that the sages were considered to have "descended from Heaven" during the Han Dynasty, whereas the neo-Confucians shared the belief that the way of becoming a sage could be studied by mortal beings. Neither the sages themselves nor their virtue were understood by neo-Confucians as being produced solely by Heaven, but also by the "power" of men. ${ }^{34}$ Tang's outlook is indeed in line with most neo-Confucian notions of sagehood in that he associated sagehood with an elusive spiritual state that is attainable by every human being, even though it remains, in fact, inaccessible for the vast majority of believers. By the same token, Tang followed his neo-Confucian predecessors by downplaying the influence of Buddhist teachings in shaping neo-Confucian ideas about sagehood. ${ }^{35}$ The human "self-belief" (zi xin 自信) in the spiritual potency of becoming a sage is said to set Confucian religiosity apart from the world religions. Yet Tang also conceded that Chan Buddhism, Christian mysticism, and the Daoist teaching of the all-encompassing truth (quanzhenjiao 全真教) contain similar ideas. ${ }^{36} \mathrm{He}$ even hints at a basic convergence of Confucianism and Daoism in

32 Tang, "The Development of Ideas of Spiritual Value in Chinese Philosophy" [1959], p. 33.

33 The translation of tian li as "principles of Heaven" stems from the English text: Tang, "The Development of the Concept of Moral Mind from Wang Yang-ming to Wang Chi," p. 188. Although this translation is not Tang's own, it is likely that he approved of it, since he discussed the difficulties of translating Chinese concepts into English at length, and at times took issues with prevalent terminology of translation (see below on liang zhi).

See Tang, Wenhua yishiyu daode lixing, p. 522; Tang, Zhongguo renwen zhijingshen fazhan, pp. 25-26. On the sage in an ideal humanistic world, see Tang, Renwen jingshen zhi chongjian, p. 63. In the following, "sage" will be used with respect to Tang's speculation, even though Tang's usage of the term is ambivalent. At times, he used terms like sheng xian 聖賢 ("sages and worthies") and sheng ren in an apparently colloquial way to refer to individuals of a "personality of highest integrity" who bear great responsibility for society and therefore deserve special reverence from others; see e.g. Tang, Wenhua yishiyu daode lixing, pp. 288, 612; Renwen jingshen zhi chongjian, pp. 63, 65, 395-396.

35 For a highly instructive overview of notions of the sage and sagehood in the Chinese context, see Angle, Sagehood: The Contemporary Significance of Neo-Confucian Philosophy, pp. 14-17.

36 Tang, Zhongguo renwen jingshen zhifazhan, p. 369. 
their belief that Heaven achieves its self-fulfillment in the "great person" ( $d a$ ren 大人), the "sage," the "true person" (zhen ren 真人) or the "Heavenly person" (tian ren 天人). ${ }^{37}$

A key aspect of Tang's understanding of sagehood concerns temporality: Sagehood is conceptualized as an ephemeral, intuitive state that is, in fact, not to be mistaken for an enduring form of social existence. The "sage" embodies at once the actualization of human nature and the self-realization of Heaven, but he is not a figure of historical temporality. Tang consequently refrained from depicting a historical perspective of a society governed by sages. ${ }^{38}$

It is significant that Tang explicitly referred to the transcendent breakthrough of the individual who becomes a sage as a "religious intuition" (zongjiao de liang zhi 宗教的良知). ${ }^{39}$ In his theological metaphysics, such intuition is not a mental activity of an individualized subject, but the working of the ultimate reality, ${ }^{40}$ i.e. the mind's convergence with self-illuminating

37 Tang, Zhexue gailun, Vol. 22, p. 362.

$3^{8}$ Metzger takes Tang's reference to the topic of becoming a sage at face value, thus portraying him as a stern, ideologically misguided believer in the feasibility of a permanent and comprehensive actualization of human nature on a social scale; see, for example, Metzger's discussion of a passage from Shengming cunzai yu xinling jingjie: Metzger, $A$ Cloud across the Pacific. Essays on the Clash between Chinese and Western Political Theories Today, p. 238. As I will argue below, this interpretation misses the point of Tang's civil theology. Although Tang's late metaphysical work Shengming cunzai yu xinling jingjie is strewn with soteriological expectations and inklings to salvific history, his political thought clearly highlights the idea that individuals may attain the state of sagehood only in fleeting moments, thus remaining for the most of time in an imperfect world. This indeed may not prevent the believer from having faith in the possibility of achieving a perfect world populated only by sages, but the thrust of Tang's political thought is not based on a "faith in the practical possibility of the world's total moral transformation" as Metzger would have it (Metzger, ibid.). In fact, Tang was well aware of the ideological dangers involved in such a vision (for his critique of the notion of a "great uniformity" [ $d a$ tong] see Chapters 4 "Defending authenticity," 12 "Overcoming totalitarianism?" in this book).

39 Tang, Renwen jingshen zhi chongjian, p. 593 .

40 Tang followed here a fundamental assumption of Lu Jiuyuan and Wang Yangming: see Shimada, Die neo-konfuzianische Philosophie, p. 133. As regards modern Confucianism, Tang related his metaphysics to the speculation of Xiong Shili and Mou Zongsan, but not to Feng Youlan's who was, as Mou recalled, rebuffed by Xiong for claiming that liang zhi was a mere "hypothesis" (jiading 假定) of the subjective mind, and not a (spiritual) fact; see Mou, Wushizishu, p. 88. 
"principles" of Heaven. ${ }^{41}$ Tang rephrased this notion many times. We find, for example, the statement that the "way of Heaven," to be understood as the process of change of all reality, becomes manifest within the empirical "reality of phenomena" in "the way of man." The latter is thus said to culminate in the intermediation of the mind of Heaven by the human mind in the act of intuition. Through this intermediation, the "self-realization of the way of Heaven" is achieved. ${ }^{42}$ As co-creator, the human being is not a creature, but rather, as it were, Heaven in the making. What unfolds is a "relationship of mutual preservation and merging"43 in the course of which the human being "enriches" reality as produced by Heaven. ${ }^{44}$ In this respect, Tang's theological metaphysics is not in line with the metaphysical realism developed by Fichte, who did not elevate the human being to the position of co-creator and identified, in his later work (after 1801), the "absolute being" with "God." ${ }^{45}$

The fact that one may discern the above-mentioned double-principle in Tang's speculation does not mean that he was following Fichte specifically, since the double-principle has had several proponents in the Western history of metaphysics, as Max Scheler reminds us: "It is this old notion of Spinoza, Hegel and many others: the original being ("das Urseiende"-TF) becomes aware of itself in man in the very same act in which man sees himself based in it." Scheler went on to observe critically that this tradition has been represented so far in a way that was "far too one-sidedly intellectualistic." Instead, he proposed to reinterpret the idea of self-realization to the effect that, in correspondence with the "ideal demand of the deity (Deitas)," self-realization is seen as "a consequence of the active installment of the center of our being." Scheler continues:

The place of this self-realization-we can also call it self-deification (Selbstvergottung) - which the being-that-exists-through-itself (Durchsich-seiende-Sein) seeks and, for the sake of its coming into existence, it puts up with a "history" - this is indeed man, the human self and the human heart. These form the only place of becoming god which is within our reach. ${ }^{46}$

Tang, “The Spirit and Development of Neo-Confucianism," p. 79; see also Wang, Chuan xi lu, p. 130.

42 Tang, Wenhua yishi yu daode lixing, p. 369.

43 Tang, Renwen jingshen zhi chongjian, p. 587.

44 Tang, Wenhua yishi yu daode lixing, p. 369; see also Wang, Chuan xi lu, p. 211 (Chan, Instructions for Practical Living and other Neo-Confucian Writings by Wang Yang-ming: II.135).

45 On Fichte see Oesterreich, Der ganze Fichte, pp. 228, 237.

46 Scheler, Schriften zur Anthropologie, p. 215 (there are all my translations; all emphases are Scheler's). 
Tang would have agreed with Scheler's strong emphasis on the active, participatory part of the human being in the course of the self-realization of the absolute, though he would not have identified his notion of Heaven with Scheler's monotheistic notion of god. For Tang, the vision of the human being as Heaven in the making is indeed one of the salient features of the Confucian religious faith. Nevertheless, he did not consider the notion of the absolute's self-realization as an exclusively Confucian idea, but as being wide-spread within Eastern and Western traditions. Significantly, he referred to the absolute with a whole range of different terms such as "Heaven," "deity" (shen 神), "tathatā, bhūtatathatā" (zhenru 真如), the "supreme ultimate" (taiji 太極), and "Brahman."47

At this point, we may thus identify several key elements of Tang's theological agenda. The first of these is the exposition, explanation, and systematization of what Tang varyingly called "faith," "philosophical faith," "feelings of transcendence," etc. At the core of this theological discourse we find: (a) the notion of an absolute, non-personal "Heaven" which achieves its full realization in the mind of the sage; and (b) the notion of the human being's inborn longing to overcome his detachment from "Heaven" by transcending his individual existence (thereby becoming a sage, i.e. a co-creator or a Heaven in the making). The second key element is the infusion of the modern Confucian ethos of individual self-fulfillment with theological limit-concepts of intuition and sagehood. These positive limit-concepts fulfill an orienting function with respect to the individual's conduct of life. They are positioned, as it were, precisely on the border between social reality, on the one side, and the realm of ultimate reality, on the other. Thirdly, even though Tang's theological Confucianism does not advocate clerical or liturgical institutions, let alone a Confucian church, his notion of a Confucian religiosity entails propositions about the form and meaning of ritual practices. The fourth key element pertains to the civiltheological taxonomy of human knowledge and cognition based on the limitconcepts of intuition and sagehood as its rationale. In accordance with these limit-concepts, the taxonomy of knowledge and cognition neither contains sacred scriptures nor an orthodox canon of classics. And, lastly, the fifth key element concerns the stipulations for the "true" philosopher, which include a messianic sense of mission.

47 Cf. Cheng, Karl Barth and Tang Junyi on the Nature of Ethics and the Realization of Moral Life: A Comparative Study, p. 318. 


\section{The Taxonomy of Knowledge and Intuition}

Tang's civil-theological taxonomy of knowledge and intuition serves as a frame of reference for integrating the political, moral, religious, cultural, and historical aspects of modern Confucianism. The point of departure for establishing this taxonomy is Tang's decision to accord a higher status to the intuitive cognition of the principles of Heaven than to discursive knowledge (in philosophy, metaphysics, and the special branches of science). Specifically, the highest level of cognition is said to be achieved in an act of intuition. ${ }^{48}$ This accentuation, however, does not amount to a denial of the relative autonomy of science and philosophy. They are rather affirmed by the taxonomy as forms of rational knowledge on an intermediate level.

In a historical and comparative perspective, all claims to universally valid definitions of philosophy are highly problematic, as Tang stated. He further elaborated that the contemporary Chinese neologism for "philosophy," zhexue 哲學, is not identical with Western concepts of "philosophy." Zhexue is far more comprehensive than what is usually referred to as "philosophy" in the West and includes Chinese, Western, and Indian philosophies in a very broad sense. ${ }^{49}$ Moreover, Tang reminded his readers that there is no generally accepted definition of philosophy in the West, and that probably every Western philosopher would answer differently the question "What is philosophy?" He added the observation that Western books presenting an overview of philosophy often fail to offer a definition of philosophy and, further, that even those authors who provide such a definition, tellingly, usually put it at the end of the book. ${ }^{50}$

These terminological and conceptual difficulties of defining philosophy notwithstanding, Tang arranged philosophy, i.e. zhexue, within the civil-theological taxonomy of knowledge and intuition. The taxonomy is structured according to the rationale of forms of knowledge that assist the human mind in attaining an intuitive apprehension of the absolute. Within this taxonomy, philosophy is situated between the fields of scientific research and the intuitive realization of the "principles of Heaven." With respect to this intuitive realization, philosophy has two supreme functions, both of which are related to

48 Ibid., p. 567. This assumption entails a notion of a spiritual self who attains intuition and is thereby able to pass correct judgments on the whole range of human behavior; see Tang, Renwen jingshen zhi chongjian, pp. 585-586.

49 Tang, Zhexue gailun, Vol. 21, pp. 16, 19-20. On this topic see also Peng Guoxiang's close reading of the prefaces and the first section of Vol. 1 of Zhexue gailun (pp. 1-33): Peng, “Tang Junyi de zhexue guan-yi 'Zhexue gailun' wei zhongxin," pp. 111-117. 
the notion of intuition (liang zhi) as an act of realization, which is locatedto use an image in line with Tang's own allegorical language - on the very border of philosophical reflection: liang $z h i$ is neither completely detached from discursive philosophy, nor is it a process of philosophical reflection.

The first function of philosophical reflection is to initiate the opening of the human mind in order to allow intuition to take place. To this end, philosophy reflects on the many forms of reification of the human subject's relation to itself and to the social and natural environment. In the course of such reflection, the human being may become aware that it is not restricted to its empirical self, but able to transcend the empirical self to reach beyond the realms of reification. In his An Outline of Philosophy (Zhexue gailun), Tang called this type of philosophical reflection "transcendental reflection" (chaoyue de fanxing 超越的 反省) and explained: “The transcendental-reflective method means that we do not attach ourselves to but transcend our speech, understanding, knowledge of existence, and value." ${ }^{51}$ According to Shun Kai Kevin Cheng, Tang intended here to delineate the "center of all philosophical method."52 But if we are to comprehensively analyze Tang's concept of philosophy, it will be insufficient to solely rely on this statement about philosophical method. What needs to be considered are the limits of philosophical reflection as outlined by Tang himself. Cheng assumes that in Tang's vision " $t]$ he decree of Heaven is revealed in the present immediacy,"53 and that this "immediacy" is fully embedded in philosophical language and reflection i.e. transcendental reflection. However, Tang's notion of intuitive immediacy points to a deep gap between the philosophical (transcendental-reflective) initiation of such intuitive immediacy and the very act of intuition itself. As shall be shown below, this notion of a gap plays a crucial role in determining the function of philosophy in general, and metaphysics in particular as building a "bridge" for human consciousness to cross into intuition. When depicting the function of philosophical language, Tang suggested the image of opening a gate to one's own spirit and to all existence, and referred to the philosophical soliloquies of St. Augustine, Zhuangzi and Kierkegaard which took, according to him, the form of prayers. ${ }^{54}$

51 Quoted from: Cheng, Karl Barth and Tang Junyi on the Nature of Ethics and the Realization of Moral Life: A Comparative Study, p. 294.

52 Ibid., p. 295 .

53 Ibid., p. 324; Cheng refers here to Tang, Shengming cunzai yu xinling jingjie, Vol. 24, pp. 233 f.

54 See Tang, Shengming cunzai yu xinling jingjie, Vol. 24, pp. 520-521. The speculation about the fundamental gap between philosophical reflection and immediate, intuitive cognition (liang zhi, "wisdom" etc.) constitutes a central issue in modern Confucianism. For 
The second function of philosophical reflection is to devise discursive representations of intuitive cognition. These representations include core elements of Confucian religiosity, namely, the individual's spiritual self-assurance that human nature as endowed by Heaven calls the human being to transcend its empirical self and achieve immediate unity with Heaven. Philosophy takes here the form of a "teaching" (jiao 教) which is inscribed into the framework of Confucian theology. Tang highlighted the importance of philosophical teaching in a mystifying retrospection of his own intellectual development. Looking back at the past 30 years, he declared that the point of departure of his philosophical development was a "feeling of transcendence" (chaoyue de ganqing 超越的感情) which led him to experience manifold "awakenings to transcendence” (chaoyue de huiwu 超越的會晤). This statement is even more remarkable for it is one of the very rare instances where Tang at least hinted at the effects that such a spiritual awakening might have on an individual's conduct of life. As regards the theological foundation of philosophy, he explained the philosophical "transformation [of the individual] through teachings" (jiaohua 教化) consists of familiarizing oneself with the many contradictions between different philosophical schools and ideas. Such contradictions, after all, are due to a "secret intention of Heaven." Tang consequently professed that he himself hardly ever intended to devise theories, preferring instead to reflect on a constellation in which mutually contradictory statements contribute to intuitively "accomplishing the teaching" (cheng jiao 成教). 55

Both philosophical tasks are obviously difficult to achieve, and the latter is particularly challenging since intuition is, from the standpoint of symbolic representation, elusive by necessity. Any attempt to translate intuition into terminologies and grammatical structures can at best amount to an accommodation. Even so, philosophy, and especially metaphysics, assumes a leading role among the various types of symbolic rapprochement with intuition. It is telling in this context that Tang repeatedly attested to the great significance of the religious orientation of his philosophy by highlighting personal experiences of spiritual

example, Mou Zongsan's philosophy also highlights the problem of reflection about such a gap. As Sébastien Billioud shows in his excellent study of Mou Zongsan, this becomes particularly evident in the context of Mou's moral philosophy. Billioud concludes that Mou "does not provide enough elements to enable us to better characterize (hence, better understand) the noncausal links between the radical rupture implied by dunwu [sudden enlightenment-TF] and an intermediate process of moral integration that takes place through retrospective verification;" see Billioud, Thinking Through Confucian Modernity, p. 226; also cf. Ibid., pp. 218-232 for a comprehensive discussion of this issue. Ibid. 
awakening. ${ }^{56}$ The origin of philosophy is, if we are to follow Tang, a yearning for transcendence- "a specific uncertainty" of the human being longing to "transcend" the "limitations" of its consciousness (in an intuitive perception of Heaven). Thus, philosophy shall lead to intuition, while remaining separate from the non-rational perception of Heaven itself. Human beings may, through philosophy, attain a discursive "self-consciousness" (zijue 自覺) of the "wholeness of their spiritual potency" (qi xinling zhi quan 其心靈之全), which initiates their "turning back" to the "source" of all knowing and which cannot be gained by strictly compartmentalized scientific activity. ${ }^{57}$ It is at this point that the "realm of void potency of the mind" (kong ling xin jing 空靈心境)—a state which itself remains aloof from philosophical thought-might be reached. ${ }^{58}$

The delineation of the "realm of void potency of the mind" serves as the background for a concept of philosophy that outlines the unity of all sciences. Yet Tang was most of all interested in conceptualizing philosophy in terms of a human mind-set, or "spiritual attitude" (jingshen taidu 精神態度). ${ }^{59}$ After all, he did not accept the claim of inductive metaphysics which sets out to construct a comprehensive world view by delineating a synopsis of all branches of science. According to Tang, this "formal idea" of a "philosophical synthesis" of all branches of science cannot be achieved anymore in a modern world of rapid evolution of knowledge. Inductive metaphysics is only of interest to Tang insofar as it shatters the respective claims to a totality of knowledge within specific branches of science and, at the same time, points toward the urge of the human mind to reach beyond the range of scientific knowledge. Hence, the pursuit of a uniform foundation of the various systems and orders of knowledge is relevant for the emergence of a "pure consciousness of a transcendent and all-embracing disposition" (chuncui zhi ju chaoyuexing hangaixing zhi $y i s h i$ 純粹之具超越性涵蓋性之意識). ${ }^{60}$ In turn, this can lead the human mind to an awareness of an ultimate reality. ${ }^{61}$

Tang suggests that intuition is neither bound to scientific systems of knowledge, nor to specific scientific methods, theories or discoveries, and it clearly cannot be understood as a synthesis of empirical or theoretical knowledge.

56 Cf. Tang, Renwen jingshen zhi chongjian, pp. 556-589 and Shengming cunzai yu xinling jingjie, Vol. 24, pp. 453-524.

Tang, Renwen jingshen zhi chongjian, p. 576; on the "turning back" see Tang, Wenhua yishi yu daode lixing, p. 369 .

$5^{8} \quad$ Tang, Wenhua yishi yu daode lixing, pp. 364, 373.

59 Tang, Renwen jingshen zhi chongjian, p. 563.

6o Tang, Wenhua yishiyu daode lixing, pp. 355-356.

61 Ibid., pp. 353, 366. 
Metaphysics, too, is not exempt from this limitation of discursive knowledge in comparison with intuited cognition. Consequently, Tang conceptualized the function of metaphysics as a sort of philosophical meditation on the limits of human cognition, on the essentially irrevocable human aspiration to overcome these limits, and on the human potential to do so in an act of intuition. But metaphysical reflection, as Tang understood it, does not necessarily have to lead to a new system of knowledge. The value of metaphysics ultimately lies in its function to question or even destroy all forms of "relative knowledge," including metaphysical systems themselves.

As a result of this destruction of knowledge, the "realm of void potency of the mind" may (suddenly) become accessible to the human mind. Tang therefore spoke of metaphysics as a bridge leading from symbolically represented cognition to the immediate presence of intuitive knowing. ${ }^{62} \mathrm{He}$ emphatically reminded his readers that one should attempt to cross this bridge without lingering on it. ${ }^{63}$ At this point, there is a clear shift of emphasis in Tang's thought in favor of a non-intelligible ultimate reality. ${ }^{64}$ This sharp line of demarcation between discursive thought and intuition separates Tang's theological metaphysics from earlier Confucian and neo-Confucian speculation, which did not construct such a tension between philosophical and theological metaphysics. ${ }^{65}$ Insofar as meditation in metaphysics leads one to the other side of the bridge, discursive thought comes to a temporary halt: In a "moment" ( $j i$ 機), the subject "realizes" (tihui 體會) "the metaphysical reality of the absolute mind and pattern” (juedui de xin yu li zhi xingshang shizai 絕對的心與理之形上實在). ${ }^{66}$ But contrary to what the bridge-allegory might seem to imply, Tang subsumed intuition itself within the notion of metaphysics, thereby proposing "metaphysics" as a term for the interlacing of philosophical and theological aspects of the study of mind and (human) nature. We may assume that he did so with respect to the above-mentioned double function of philosophy in relation to

62 Ibid., pp. 364, 373. Contrary to Henri Bergson's new metaphysics, Tang did not bind intuitive perception to a passage through the positive sciences.

63 Ibid., p. 366.

64 Arlt gives an account of Max Scheler's metaphysical anthropology which can be seen as pointing in a similar direction: see Arlt, Philosophische Anthropologie, pp. 23-24.

65 Cf. Tang's own account of neo-Confucian speculation in Tang, Zhongguo wenhua zhi jingshen jiazhi, pp. 87-91; Tang, "The spirit and development of Neo-Confucianism," p. 68.

66 For these concepts see Tang, Wenhua yishi yu daode lixing, pp. 365-366; also cf. ibid., pp. 364, 373 . 
intuition - the moment of intuition hence remains accessible to philosophical thought, even though the intuition itself transcends reflection altogether.

Within the framework of his theological speculation, Tang interpreted the transcendental philosophical reflection on the categorical limits of cognition as the liberation of the human mind from dogmatic fetters. He described this in Buddhist terms as a spiritual initiation to the "unpinning" (chaoba 超拔) of the consciousness from its "limitations," and thus as an "appearance" of the “non-'limited'” (wu “xian" 無 “限”-Tang's emphasis). ${ }^{67}$ This vision amounts to a post-transcendental return to theological metaphysics. It entails the claim that the ultimate reality will disclose itself as an upshot of the destruction of pure reflection and of the Kantian self-limitation of transcendental philosophy. From this perspective, Kant's transcendental reflection on the constitution of empirical cognition is seen as a philosophical impetus to the self-transcendence of the human consciousness in intuition. ${ }^{68}$ Thus, Tang's focus is not so much on the destruction of discursive knowledge per se, but rather on the taxonomical demotion of forms of knowledge prone to categorical and conceptual fixation. Seen from Tang's Buddhist-inspired aspiration of attaining intuition by pushing the mind through the breakdown of discursive thinking, Kantian critical philosophy with its insistence on conceptual and categorical thought must be restrained.

The goal in setting up such a taxonomy of knowledge is neither the construction of a methodologically defined system of knowledge, nor the formulation of an epistemology. Significantly, Tang spoke of a "very long and winding road" leading from Western philosophy and its main currents of epistemology, philosophy of science and analytical philosophy to the ultimate realm of intuition. He further assumed that while travelling along this road, one may easily be bogged down by "intellectualism." But this should not be mistaken as an attempt by Tang to initiate a struggle of Western science and philosophy vs. Eastern philosophy for supremacy over the construction of a modern world view. On the contrary, he explicitly stated that the road of Western philosophy was "more suitable for the present age."69 Instead of supporting an opposition to Western science, modern Confucianism aspires to a mutual

\footnotetext{
67 Tang, Zhongguo wenhua zhi jingshen jiazhi, p. 100.

68 Tang's approach must be clearly distinguished here from Scheler's philosophical anthropology which defines philosophy in a fundamental sense as "evidential cognition of essence" (evidente Wesenserkenntnis) and, in contrast, portrays neo-Kantian philosophy as an absurdity; Arlt, Philosophische Anthropologie, p. 84.

69 Tang, Renwen jingshen zhi chongjian, pp. 577-582.
} 
relief or task-sharing with an allegedly over-burdened scientific world view. Scientific research cannot bear fruit if it is supervised, at every step, by moral considerations. The manifesto of 1958 bluntly states: "The crucial point—why the Chinese lack this kind of scientific spirit-is basically the overemphasis on moral practice in Chinese thought." ${ }^{70}$ Regarded from the standpoint of its social functions, Tang's modern Confucianism set out to embrace scientific and technological progress in much the same way as religions may do in Western societies of the post-Enlightenment age. ${ }^{71}$

\section{Limits of Philosophical Exposition}

Tang's writings are characterized by an unusual, hybrid style that cannot, first of all, be clearly identified as either written vernacular Chinese (baihuawen 白話文) or classical literary Chinese (wenyanwen 文言文). While the hybrid nature of his writing style requires further research, Anja Steinbauer had made an astute observation of two characteristic traits of his style: 1) Tang's texts are abundant with passages where he introduced terms as if he "expected from his readers an associative and intuitive understanding [of these terms];" 2) Steinbauer discerns a tendency of Tang to compose very long sentences with utterly complex grammatical structures, which are difficult to understand. It seems to her that Tang tried to "overcome the limitations which were imposed on him by language as a vehicle-if not through a deliberate attempt to break (these limitations) up, then at least through non-observance [of conventions of academic writing]. ${ }^{\prime 2}$ We may suppose that Buddhist inspirations again come into play here. The peculiarities of Tang's writing style seem to convey his concern about the limits of philosophical exposition as a means to attain intuitive insights, but also as a medium suitable for giving an account of intuition itself. Besides, when immersing oneself in Tang's texts, one almost cannot help but suspect that he deliberately chose to express himself in a thorny style. Perhaps

$70 \quad$ Zhang, Zhongguo wenhua yu shijie, p. 34.

71 On this aspect of religions in modern Western societies, see Lübbe, Religion nach der Aufklärung.

72 Steinbauer, Tang Junyis System der neun Horizonte des Geistes, pp. 103, 105 (English translation: TF). Thaddeus Hang (Xiang Tujie) came to a similar conclusion in an article on Tang Junyi and Xiong Shili published in 1979, when he critically remarked that “... [r] eading the writings of Mr. Tang, ... I feel that they are suffused by literary and poetic sense rather than strict logical reasoning."; quoted from: Cheng, Karl Barth and TangJunyi on the Nature of Ethics and the Realization of Moral Life: A Comparative Study, p. 297. 
he wanted to slow his readers down and draw them deeper into a meditation on the text, or to at least provide his readers with a first-hand experience of his own struggle with language as an inadequate vehicle for a speculation about intuition. Viewed from this perspective, both reading and writing seem to be part of a philosophical-meditational practice of self-fulfillment. The fact that Tang's writings abound with frequent and tedious rephrasing of statements substantiates this assumption.

Moreover, it is conceivable that he wanted to express, at a formal level, his suspicion of modern scientific civilization: his allusive, allegorical, at times obscure writing style should serve as an antidote to modern tendencies to reify human existence under conditions of instrumental rationality and, accordingly, to restrict the human mind. We can furthermore assume that Tang tried to bring the form (style) of his writings into complete accordance with his basic philosophical intention in this way. He apparently aimed for a totality of authentic expression by creating a type of philosophical exposition which generated a coherence between philosophy and intuition, not only in terms of their content, but also in formal and linguistic respects. Such coherence could not, as we have seen, take the form of a conceptual (Western) philosophical language. The quest for authenticity here refers, first of all, to the philosopher who, by aiming at an intuitive insight, relativizes conceptual claims to truth and thereby tacitly acknowledges linguistic and terminological ambiguity. This in turn accords with the peculiarities of Chinese philosophy as Tang identified them. He contended that the language of Chinese philosophy "merely" fulfills the function of a makeshift bridge between the existential and spiritual realm. After the bridge is crossed, it is "transcended." Theoretical/philosophical reflection, in other words, has no exclusive claim to truth. It is as provisional as other truth claims. Besides using language of a "theoretical nature," Chinese philosophers, according to Tang, also placed great importance on a "literary" language and the forms of philosophical dialogues and letters. ${ }^{73}$

73 Tang, Zhonghua renwen yu dangjin shijie, Vol. 8, pp. 420-421. In the course of a recent discussion about whether some of Tang's works should be "rewritten" in a more accessible style, as Wu Rujun has suggested, Zhao Jingbang quotes a passage from Tang's Rensheng zhi tiyan that indicates the quasi-soteriological function of language in Tang's work. Tang states that in his "written language" (wenzi 文字), he deliberately let "the margins of the realm of $l i$ 理 become enveloped in fog." He apparently believed that his writings were thus "even richer in evocativeness and guiding [function]," which in turn caused his "spirit" (jingshen 精神), upon reading his own texts, to "ascend to this realm of $l i$ with even more ease." See Zhao, "Dui Wu Rujun xiansheng jianyi chongxie Tang Junyi xiansheng zhuzuo de yi xie fansi," pp. 119-120. 
A further attempt to integrate form and content can be detected on the level of terminology in Tang's thought. In Tang's usage, zhexue, as we have seen, has a very broad scope, comprising Chinese, Indian and Western traditions. This notion of zhexue has repercussions on the philosophical vocabulary in Tang's texts. Hence, we find passages where Tang paralleled neologisms and terms from pre-modern Chinese thought to denote the same notion, for example juedui 絕對 / tian li 天理 as a pair within the semantic field of the absolute. In other instances, he indicated the flexibility of the Chinese philosophical vocabulary by using the same Chinese word for different philosophical notions (Western or Chinese), depending on its use as terminology for the translation of Western philosophy, or as terms stemming from pre-modern Chinese philosophy. This holds also true for the core concept of liang zhi. Tang introduced several terms to delineate his notion of intuition, but he clearly singled out the term liang zhi. With the use of liang zhi, he explicitly referred to the thought of Wang Yangming and his followers. In fact, he considered the theory of liang zhi to be at the center of Wang's philosophy, ${ }^{74}$ which he described as the climax of the Mencian theory of human nature. ${ }^{75}$

Tang himself was reluctant to translate liang zhi into English, refusing to use the common English translation "innate knowledge" and relying, instead, on the transliteration "liang-chih."76 The terminological difficulties do not end here, since Tang, in his discussion of British philosophy, translates the term "conscience," apparently without hesitation, as liang zhi in Chinese. Yet, this should not be taken as a hint to, conversely, translate liang zhi in the context of Confucian philosophy simply as "conscience." The ambiguities surrounding Tang's references to liang zhi in Chinese and English serve as a reminder that his philosophical vocabulary is highly stratified and open to complex crossreferences. ${ }^{77}$ Perhaps unsatisfied with the transliteration "liang-chih," but unable to coin an adequate English translation, Tang proposed several English expressions as equivalents. Obviously, the results of his effort failed to convince even himself — rightfully so, one may add, as his translations indeed offer

74 Tang, "The Development of the Concept of Moral Mind from Wang Yang-ming to Wang Chi," p. 188. On the topic of "liang zhi," Tang recommended Mou Zongsan's Wang Yangming zhi zhi liang zhi zhi jiao 王陽明之致良知之教: Tang, Renwen jingshen zhi chongjian, p. 587 .

75 Tang, "The Development of Ideas of Spiritual Value in Chinese Philosophy" [1968], p. 6.

76 See his remarks in Tang, "The Development of the Concept of Moral Mind from Wang Yang-ming to Wang Chi," p. 188.

77 Tang, Zhexue gailun, Vol. 2, index p. 39; see also Tang, "The Development of the Concept of Moral Mind from Wang Yang-ming to Wang Chi." 
little help. Some of these translations even create new problems, for example the highly interpretative translation of liang zhi as "consciousness of $l i$ " (理). First of all, in the semantic field of intuition, the term "consciousness" must be understood in a very broad sense (namely, designating a state of mind where the distinction of subject and object is not present). Furthermore, Tang created more translation problems with his use of another transliteration $(l i) .^{78}$ The same may be said, mutatis mutandis, of other translations of liang zhi into English introduced by Tang in various of his writings: "conscientious consciousness of mind";79 "original-good-conscientiousness" (a translation which should express, according to Tang, the fact that liang zhi was not just "original knowing," but also has a derivational meaning of "good," and is always "sensitive" towards "values of good") and "original-good-conscientious-knowing"; 80 Tang also proposed "moral consciousness" and "being of the moral mind" as possible translations, hence positioning liang zhi unmistakably in the field of moral philosophy. ${ }^{81}$

Tang's struggle with a conceptual fixation of liang zhi seems to be less a matter of a struggle with language than about language and its limitations for discerning the inner workings of intuition. Consequently, he tried to coin adequate terms not only in English. As for Chinese terms introduced by him to refer to liang zhi, they also serve as testimony of his difficulties to conceptualize it. We find, for example, the following terms relating to Tang's idea of intuition: "the wisdom (zhihui 智慧) of realizing metaphysical reality;" ${ }^{82}$ or just the "absolute... cognition (juedui 絕對...zhishi 知識)." ${ }^{83}$ Neither zhihui nor zhishi adequately convey Tang's understanding of liang zhi as intuition in $a c t u$. More helpful for a tentative conceptual approach to liang zhi are perhaps the following: "immediate awareness;" 84 to "realize" the "metaphysical reality of absolute mind and pattern;" 85 and "to know" "mind" and "[human]

\footnotetext{
78 Tang, "The Spirit and Development of Neo-Confucianism," p. 8 o.

79 Ibid., p. 79 .

8o Tang, "The Development of the Concept of Moral Mind from Wang Yang-ming to Wang Chi," p. 188.

81 Tang, "The Spirit and Development of Neo-Confucianism," p. 80.

82 Tihui xingshang shizai zhi zhihui 體會形上實在之智慧: Tang, Wenhua yishi yu daode lixing, p. 367 .

83 Tang, Wenhua yishi yu daode lixing, p. 359.

84 Zhi jue 直覺: Tang, Wenhua yishi yu daode lixing, p. 363 and Tang, Renwen jingshen zhi chongjian, p. 567 .

85 Tihui 體會, juedui de xin yu li zhi xingshang shizai 絕對的心與理之形上實在: Tang, Wenhua yishi yu daode lixing, p. 365; see also: “to realize" (tihui), “this mind" (cixin 此心) and "this pattern" (ci li 此理) Ibid., p. 366.
} 
nature." 86 As we have seen, Tang called the spiritual state in which the human being is prepared to attain intuition the "void potency and bright awareness of the mind." 87 The terms $x u$ ling 虛靈 (void potency) and ming jue 明覺 (bright awareness) also figure in Wang Yangming's reflection on intuition to indicate that the immediacy of intuition is "void" insofar as intuition is neither bound to sensory perception, nor restricted to other modes of experience. ${ }^{88}$ Significantly, the original state, in which Heaven is in motionless self-identity, is often referred to in the neo-Confucian vocabulary as the "great void" (tai xu 太虛). The dynamic notion of an identity of Heaven and human mind in the act of intuition requires the human mind, according to Wang Yangming, to achieve a state of "great void" in which it is able to attain intuition. ${ }^{89}$

Like Wang Yangming before him, Tang used allegorical language to describe the process of intuition. Allegories of light play a particularly important role, as Tang took up two allegories from Wang Yangming's Chuan xi lu, one depicting eyesight, the other sunlight. ${ }^{90}$ In his analysis of these two allegories, Tang introduced the conceptual pair of substance and function, but without any intention of proposing a definition of the absolute as a substance in the sense of an ontological difference between substance and function. The absolute is said to manifest itself in a permanent process of becoming, which creates all reality, but this is not meant to imply that substance precedes its own manifestation (or functions). On the contrary, the terms "substance" and "function" apply to the idea that substance and function are inseparable in the ongoing, permanent manifestation of the absolute itself. Similarly to the "substance" of eyesight, which does not simply exist as eyesight as such, but only in its "function" of perceiving colors, the "substance of the mind" (xin zhi benti

$86 Z$ Zhi 知, xin 心, xing 性: Tang, Zhongguo renwen jingshen zhi fazhan, p. 371.

87 Xin zhi xu ling ming jue 心之虛靈明覺: Ibid., p. 363 .

88 Wang, Chuan xi lu, p. 477 (Chan, Instructions for Practical Living and other Neo-Confucian Writings by Wang Yang-ming: III.274): xu ling; and p. 334 (ibid., III.174): ming jue.

89 Wang, ibid., p. 472 (Chan, ibid.: II.269).

9o Tang, "The Development of the Concept of Moral Mind from Wang Yang-ming to Wang Chi," pp. 189, 194. Tang's references to 3.19 (allegory of sunlight) and 2.19 (allegory of eyesight) are based on an edition the Chuan xi lu from 1917 (Shanghai) which I have not been able to cross-check. His reference to "3.19" is probably identical with Wang, Chuan xi lu, p. 486 (Chan, Instructions for Practical Living and other Neo-Confucian Writings by Wang Yang-ming: III.282) according to the prevalent arrangement of the text. I was not able to locate the allegory of eyesight. 
心之本體)—i.e. the "pattern of Heaven"91_exists inasmuch as the mind manifests itself in liang zhi. ${ }^{92}$ The allegory of sunlight also illustrates this notion of substance: where there is light, there is a sun. Accordingly, the absolute is referred to as the "substance of liang-chih's substance" - in other words as the "substance" of a human mind attaining liang $z h i{ }^{93}$

As the absolute emerges in the human mind by shining into it, liang zhi manifests itself as a vision or illumination in the mind that takes the form of intuition in actu, i.e. of a "happening" ( $s h i$ 事). ${ }^{94}$ At the same time, the absolute recognizes itself in the light which shines into the mind: Liang zhi, therefore, is "the self-illumination and self-consciousness of the pattern of Heaven." ${ }^{95}$ In this "self-illumination and self-consciousness" of the absolute, human cognition is achieved as an immediate and affective unity of appearance and insight. This does not mean that the human mind passively "sees" or conceptualizes the absolute. After all, the latter cannot be objectified or therefore take the form of an image or a concept. Tang himself explicitly attested to the inadequacy of language to give expression to the absolute and consequently paid only scarce attention to related terminological distinctions. ${ }^{96}$

The human being's vision of the absolute is itself a phenomenon of the absolute's manifestation. Instead of conceptualizing the absolute, the human spirit should therefore try to apprehend it by intuitively taking part in it. Such

91 See Wang, Chuan xi lu, pp. 27 (Chan, Instructions for Practical Living and other NeoConfucian Writings by Wang Yang-ming: I.8), 174-175 (ibid., I.122).

92 Tang, "The Development of the Concept of Moral Mind from Wang Yang-ming to Wang Chi," p. 194. The idea that colors are not properties existing independently of perception was neither for Wang Yangming nor for Tang Junyi a matter of discussion, but one may suppose that both of them would have agreed with this idea; see also the famous allegory in the Chuan xi lu: Wang, Chuan xi lu, p. 479 (Chan, Instructions for Practical Living and other Neo-Confucian Writings by Wang Yang-ming: III.275).

93 Tang, "The Development of the Concept of Moral Mind from Wang Yang-ming to Wang Chi," p. 189 .

94 Tang, Renwen jingshen zhi chongjian, p. 380.

95 Tang, "The Development of the Concept of Moral Mind from Wang Yang-ming to Wang Chi," p. 188. The expression "the self-illumination and self-consciousness of the principles of Heaven" is not my translation. The corresponding Chinese expression is tian li zhi zhao ming ling jue 天理之照明靈覺. This is an interesting case for questions concerning linguistic analysis of Tang's philosophical language. Tang obviously agreed with this translation, and thus with the interpretation of zhao ming and ling jue as reflexive expressions ("self-").

96 On this see William Ng's study about Tang's Shengming cunzaiyu xinling jingjie: Ng, "T'ang Chun-i on Transcendence: Foundations of a New-Confucian Religious Humanism," p. 296. 
participation results, according to Tang, from a complete actualization of "reason" (lixing 理性). This entails a "transcending of self-awareness" on the part of the human being. In his use of the Chinese term lixing for "reason," Tang explicitly stated that reason in the sense of lixing is not to be reduced to the function of a "universal lawgiver," since it transcends human self-consciousness. He then suggested that the term liang zhi may be used instead of lixing. ${ }^{97}$ By equating lixing with the non-conceptual and quasi transrational liang zhi, Tang obviously negated any identification of lixing / "reason" with a calculating and instrumental type of rationality. Here, Tang's thought is in general agreement with a popular critique of the European Enlightenment's philosophical naturalism and its concept of rationality. Charles Taylor regards this criticism of the "disengaged reason" of enlightenment as one of the main aspects of German, French and British Romanticism; it seems reasonable to add modern Confucianism to this list. ${ }^{98}$

\section{The Limit-Concepts of "Philosophical Faith"}

Judging from Tang's taxonomy of knowledge, the mind aspires to overcome its own limitations in all areas of human cognition, either directly or indirectly, consciously or unconsciously. The arrangement of this taxonomy follows the pattern of a spiritual and intellectual endeavor which, ideally, would lead a human being to his or her spiritual self-fulfillment. The underlying idea of this taxonomy-namely an increasing detachment of the human mind from finite states and from conditional knowledge-is very likely the

Tang, Renwen jingshen zhi chongjian, pp. 379-380. The term "lixing" is highly ambivalent in the context of modern Confucianism and it is sometimes difficult to determine whether Tang was using it as neologism (thus referring to Western philosophical vocabularies of reason/rationality) or in relation to the semantic field of "liang zhi" indicated above. In the second preface to his Cultural Consciousness and Moral Reason, Tang explained that lixing was the equivalent of what the Chinese Confucians called "xing li 性理." He equated it with the "original substance" (ben zhi 本質) or "selfhood" (zi ti 自體) of the moral self, spiritual self and transcendent self; see Tang, Wenhua yishi yu daode lixing, (author's second preface), p. 19.

98 Consider the following quote from Taylor's Sources of the Self: "The Romantic order, in contrast, was not organized on principles which could be grasped by disengaged reason. Its principle of order was not exoterically available. Rather it was itself an enigma, and one could only understand it fully by participating in it." Taylor, Sources of the Self, p. 380; see also pp. $382-384$. 
result of Buddhist inspiration. ${ }^{99}$ Tang referred to this spiritual endeavor as the attainment of "transcendental spirituality" leading the human mind towards intuition. ${ }^{100}$ This endeavor is part of a multifaceted practice which is thought to lead to the full actualization of the human being's spiritual nature. Tellingly, Tang inscribed the notion of the sage onto the "spirit of practice" of Chinese philosophy, contrasting it to what he perceived as the mainstream of Western philosophy. ${ }^{101}$ Hence, the longing of Chinese philosophers to reach beyond the conceptually knowable world and its corresponding orders of knowledge is supposedly particularly strong.

Such an understanding of philosophy highlights the "effort" (gongfu工夫) to recover the "wholeness" of a "harmonious human existence" by striving to connect diverse types of knowledge. This orientation towards the existential dimension of philosophy, by the way, stands in stark contrast to the criticism that modern Confucianism is overly theoretical and lofty (see Chap. 3 : "Dogmatism"). In fact, the outlook of Tang's modern Confucianism is in line with, and was perhaps influenced by, the concept of philosophy presented by Rudolf Eucken and other philosophers of life from the early 2oth century. Even though Eucken did not devise a civil theology, he placed great emphasis on the existential dimension of philosophical thought and highlighted the responsibility of philosophy to function as a form of intellectual engagement with social reality. ${ }^{102}$ For Tang, too, philosophy is not a purely intellectual effort. It is also a teaching which ultimately aims to "thread together" the processes of “cognition" ( $z h i$ 知) and “action" (xing 行) in an act of intuition whereby the ultimate reality reveals itself. It is thus hardly surprising that Tang introduced the term "philosophical faith" (zhexue de xinyang) in this context. ${ }^{103}$ The selfrealization of the absolute in intuition, however, is not perforce conditioned

99 Metzger's observation on the influence of the idea of pan jiao 判教 (i.e. the division of Buddha's teachings) on Tang's arrangement of different philosophical ideas seems to confirm this interpretation; see Metzger, A Cloud across the Pacific, pp. 229-230.

$100 \quad$ Tang, Wenhua yishi yu daode lixing, p. 361.

101 Tang, Renwen jingshen zhi chongjian, p. 469.

102 Zhang Junmai had visited Eucken for four months in Jena in 1920 and published a German book entitled Das Lebensproblem in China und Europa together with Eucken in 1922. On Zhang Junmai's relation to Eucken, see Fröhlich, Staatsdenken im China der Republikzeit (1912-1949). Die Instrumentalisierung philosophischer Ideen bei chinesischen Intellektuellen, pp. 140, 151, 165. On Eucken's concept of philosophy, see Lübbe, Politische Philosophie in Deutschland. Studien zu ihrer Geschichte, pp. 182-186.

103 Tang, Zhexue gailun, Vol. 21, pp. 27, 32-33. 
by philosophy, but may occur spontaneously, i.e. without prior philosophical reflection and without explicit (philosophical) faith.

Whereas the historian of philosophy can conduct research without personally "believing" in any philosophy, the "true philosopher," as Tang added in an autobiographical reference, must have such philosophical faith and a "spiritual attitude of [taking] responsibility," especially when he or she is not blessed with living in peaceful times. Otherwise, the philosopher will be nothing more than a "wandering ghost" (you hun 游魂). ${ }^{104}$ In a personal retrospection of his own work, Tang elaborated on the responsibility of the philosopher and emphatically declared that the value of philosophy has to be found in its capacity to assist individuals who wish to restore their faith by overcoming their doubts. ${ }^{105}$ Tang's enthusiasm was almost delirious when he proclaimed that a philosopher must have a soteriological intention of redeeming the world and should strive for his or her own awakening as well as that of other human beings. ${ }^{106}$ Here, Tang's idea of philosophy as a way of life points to a moral dimension. From this perspective, he discussed moral intuition which is simultaneously present as moral behavior. Through intuition, the human being apprehends "original moral principles" in the form of principles which are given to it as moral orders that in turn effectuate simultaneous moral conduct. In contrast to moral intuition, discursive moral philosophy has its origin at the very point of a discontinuity, or a "break" (duan 斷), between moral truth and moral cognition or between moral truth and conduct-in other words: moral philosophy is necessary where moral intuition is not accessible. Moral philosophy ideally evokes, according to Tang, original moral principles, which then become visible in the derived form of "principles of concrete existence." ${ }^{107}$ In that sense, moral philosophy is quintessentially the quest for a discursive recovery of moral truth, and at the same time a form of spiritual exercise to recover the individual's original moral sensitivity. ${ }^{108}$ It seems that Tang had in mind an enhancement of moral sensitivity through a continuous

104 Tang, Renwen jingshen zhi chongjian, pp. 562-563.

105 Tang, Shengming cunzai yu xinling jingjie, Vol. 24, p. 493.

106 Ibid., p. 519. Tang was convinced that those who conduct philosophical research in a strictly academic manner also fulfill an important task. Yet, by academically pondering philosophical problems, they set only themselves, and nobody else "at peace:" ibid.

107 Tang, Wenhua yishi yu daode lixing, p. 371.

108 On Tang's description of a moral way of life as characterized by continuous moral selfexamination of the individual: see ibid., pp. $5^{21-522}$. 
effort of the individual which would thus further develop a disposition to act morally. ${ }^{109}$

The theological twist of this endeavor is explicitly stated by Tang when he identified faith as the root of ethics: "In the Chinese style [of ethics], the source of the moral mind is the belief in the humaneness (ren 仁) of human nature as the humaneness of the way of Heaven."110 He further reflected, in a general manner, on the necessity of religious faith with respect to sustaining moral efforts:

We hence need to believe that behind and above all the irrationalities which we cannot but bear there should be an absolutely reasonable otherworld, a universal divine being. This otherworld or divine being is the source of our reasonable moral efforts, and it is also the highest guarantee for their authenticity, and the setting place of all moral efforts. It is this otherworld or divine being wherein the human being's metaphysical true nature and true spirit exists. ${ }^{111}$

Tang apparently did not take this claim to mean that religious faith is the cause of morality, but rather the anchorage or foundation of morality (if not in the Kantian sense). In terms of moral practice, the idea of moral intuition belongs to the same category as the related notion of the sage (who serves as a symbol of moral intuition): the status of these notions in Tang's philosophy is that of a positive limit-concept. Although Tang never explicitly referred to the notions of the sage and moral intuition as "limit-concepts," he indeed ascribed to them a limiting and orienting function with respect to the religious dimension of Confucianism, but also to its political, social and moral dimensions. As positive limit-concepts they are neither completely outside of historical and social reality nor fully inside. Or as Tang writes in a typically allusive description:

The realization of liang-chih is a way to sagehood because every man has it in himself to be a sage. We could even say that in the depth of every man's heart there lies hidden a sage waiting to be revealed when the closed door of the mind is opened. ${ }^{112}$

109 It is in this sense that Tang's following statement might be understood: The "origin" of moral judgment is "moral wisdom" and it is displayed in "moral practice:" Tang, Renwen jingshen zhi chongjian, p. $5^{8} 5$.

110 Tang, Zhongguo wenhua zhi jingshen jiazhi, p. 109.

111 Tang, Zhongguo renwen jingshen zhifazhan, p. 313.

112 Tang, "The Spirit and Development of Neo-Confucianism," p. 82. 
Sages are, then, neither god-like figures dwelling in a sphere beyond reality nor hermits living outside of the human community. Nor do they directly intervene in the human world as benevolent and wise rulers (as many philosophers from the Confucian tradition would have it). For individual members of different types of human communities, including the political community, the notion of the sage is accessible as an orienting prescription for a paradigmatic human being. Yet the sages will never appear in the guise of saintly historical figures, moral teachers, virtuous politicians, benevolent social leaders, or model intellectuals. Sagehood, in other words, is an elusive state of the absolute's instantaneous realization, and neither a form of social existence nor reflective of a superior type of moral or ethical deliberation. In turning the notion of the sage into a positive limit-concept here, Tang moved beyond the mainstream of Confucian traditions - and possibly without being guided by any other tradition. ${ }^{113}$

With his depiction of the sage as a paradigmatic figure, Tang had no intention of reducing the sage to a mere rational construct of the human mind. The notion of the sage is not a negative limit-concept that functions, in the Kantian sense, to relieve human reason from the burden of engaging in futile efforts to reach beyond the knowable. On the contrary, Tang insisted that everyone may instantaneously become a sage, even though this may not constitute a permanent state of social existence. While someone arguing from within the framework of neo-Confucian concepts of sagehood might presume that this distinction indeed means that "one could argue that sagehood was irrelevant,"114 Tang's modern Confucianism takes this distinction as a crucial element for developing renewed conceptualizations of politics, ethics and religiosity.

Given that the immediacy of a (moral) intuition in actu forgoes any symbolic representation of knowledge, insight or cognition, sagehood as understood in terms of intuition cannot constitute a state of cultivation or education. There is a fundamental gap between the cultural and educational praxis of individual self-fulfillment, on the one hand, and the instantaneous spiritual transforma-

113 Lao Sze-kwang believes that Tang, as well as Mou Zongsan, devised "limiting concepts" with respect to the perfectibility of the human being, but failed under Buddhist influence to distinguish between limiting concepts and "goal concepts" (i.e. positive concepts of something that can be actually achieved in social reality). Lao, who hardly gives any evidence to support his assumption of Buddhist influence, in fact means negative limitconcepts by "limiting concepts". Lao merely alludes here to the Buddhist idea of a "comprehensive doctrine" (yuan jiao 圓教); see Lao Siguang (Lao Sze-kwang), "Cong Tang Junyi Zhongguo zhexue de quxiang kan Zhongguo zhexue de weilai," p. 25.

114 Angle, Sagehood: The Contemporary Significance of Neo-Confucian Philosophy, p. 26. 
tion into a sage, on the other. The consequence of this gap becomes particularly evident when Tang ascertains that one can actually attain an immediate realization (liang zhi) without actual awareness of having attained it. ${ }^{115}$ The discursive inaccessibility of intuition itself impedes the individual's recounting of the intuition, and, literally, his or her ability to come to terms with it. Tellingly, Tang stated that the many efforts of what is often summarily addressed as "selfcultivation" are indeed situated as such outside of the "realm" of the sage:

... the final realm of the way of learning [to become] a sage ... is attained without effort and reached without thinking. ${ }^{116}$

One who achieves the full development of his moral life or the realization of the essence of his moral nature (jen) is called a sage in Confucianism. In the sage mind, there is no borderline of differentiation between the fully developed mind and the universe, and this kind of mind can be taken as both originated from the sage-man and revealed from Heaven. (...) The idea of "universal attainability of [being a] sage" itself may be taken as a metaphysical belief, since no empirical verification in the ordinary sense can be found. ${ }^{117}$

In contrast to human beings who cannot live in a continuous state of intuition (which would mean that they stay in an infinite realm beyond any discursive forms of communication and also beyond any symbolic representation), the sage belongs to an elusive, immediate presence. The salient characteristic of a sage is thus not a form of discursive wisdom, but his or her intuitive access to the "sublime realm" (shengshen zhi yu 聖神之域) of "knowing Heaven." ${ }^{\text {"118 A }}$ society populated by sages is consequently not within the reach of human history, and any hope that the sages could be saviors of the human world is as vain as it is misguided:

115 Tang, Zhonghua renwen yu dangjin shijie bubian, Vol. 10, p. 463.

116 Tang, Renwen jingshen zhi chongjian, p. 380. "... attained without effort and reached without thinking” is a quote from The Doctrine of the Mean 20.18. Tang also referred here to the "worthy person," but makes no distinction between the sage and the worthy, thus placing the latter in the realm of the former.

117 Tang, "The Development of Ideas of Spiritual Value in Chinese Philosophy" [1959], p. 33.

118 Tang explicitly ascribed this notion to the "orthodox school of Chinese metaphysics" (Zhongguo xingshangxue zhi zhengzong 中國形上學之正宗): Tang, Zhexue gailun, Vol. 22, p. 374 . 
But no matter how men [engage in their moral] refinement and cultivation, and no matter how they remake their [actual] conditions, in the end, they can neither enable everyone to become sages and worthies, nor have their [own] conditions conform completely to [their] ideals. There will always remain many things which can neither be transformed nor reached through human strength. It is for this reason that the opposition between the irrational and moral ideals will still persist. ${ }^{119}$

Tang emphatically asserted that even if all the sages, from antiquity to the present, were to appear in the contemporary world, they would still not be able to save the world, because they do not wield power themselves, but exist solely in the mind of all people. Any hope that sages can or will intervene in historical reality is therefore futile. What is needed instead is the willingness of the people to orientate their actions toward the sage's path. ${ }^{120}$ This is why Tang refrained from calling a society which is not governed by the moral intuition of the sages a manifestation of human failure. These limit-concepts, then, do not cause a "predicament" of imminent and constant failure, even though the sage and moral intuition are in fact beyond the reach of individuals and collectivities. Their grip on praxis is not destructive in the sense that they install standards and convey expectations for human behavior which cannot actually be met. Therefore, one cannot agree with Thomas Metzger when he stated that Tang 'conceptualized praxis as a resolute 'inner' effort to implement ideals..."121_such a narrow concept of praxis would permanently damage social reality since it would be seen solely from the perspective of unfulfilled "ideals." With his notion of limit-concepts, Tang exactly avoided this strangulation of praxis by overwhelming ideals. ${ }^{122}$

Neither the sage nor moral intuition are "ideals" in the strict Kantian sense. In The Critique of Pure Reason, Kant exemplarily cites the notion of the sage in Stoicism when stating that ideals have a practical function. According to Kant, ideals are relevant in praxis insofar as they function like "regulative principles," which means that they serve as a standard for actions ("Richtmaß von Handlungen"), albeit without prescribing specific rules for moral conduct. ${ }^{123}$

\footnotetext{
119 Tang, Zhongguo renwen jingshen zhifazhan, p. 312.

120 Tang, Zhonghua renwen yu dangjin shijie, Vol. 8, p. 429.

121 Metzger, A Cloud across the Pacific, p. 191.

122 It is, by the way, no coincidence that social figures such as the worthy (xian 賢) or the noble man (junzi 君子), who mark distinct stages on the path to sagehood in many Confucian traditions, are largely absent from Tang's modern Confucianism.
}

123 Kant, Kritik der reinen Vernunft, pp. 549-550. 
Tang assumed in the same vein that the notions of the sage and moral intuition have practical relevance, but his limit-concepts do not function as standards for actions. The insights gained by intuition are unforeseeable after all, and cannot serve as a standard for decision-making. Instead, Tang's limit-concepts fulfill their practical, regulative function by delineating and stabilizing an ethos of individual self-fulfillment. This entails another important difference between Tang's limit-concepts and Kant's ideals: Whereas Tang wanted the individual to believe that the goal of becoming a sage is, in principle, attainable, Kant not only declares that those who uphold an ideal should keep in mind that they will not be able to fully realize it, but adds that any attempt to do so will harm and weaken the ideal, because the inevitable failure to implement it would eventually make people believe that the ideal was illusory and without practical relevance. ${ }^{124}$ Suffice to say that Tang's limit-concepts have even less in common with Kant's "pure concepts of reason" than they have with Kant's notion of an ideal. ${ }^{125}$

\section{Ibid.}

125 "God," according to Kant, is a pure concept of reason, which means that reason needs such a notion of "an absolutely necessary being" ("absolut notwendige[s] Wesen") to regulate the intellect. But the fact that reason needs the idea of "God" is of course not to be mistaken as a proof of an "objective reality" of god-it is, after all, a "mere idea" ("bloße Idee"): ibid., p. 567. Concepts of reason, or "ideas," find their symbolic objectification, according to Kant, in "ideals" which function, as mentioned above, as a yardstick or standard for action, see Baruzzi, “Kant," pp. 152-153. 